\title{
Studying the Inter-relationship amongst the Success Factors behind e-tailing of Indian Female Apparels
}

\author{
Indumati \\ Tata Consultancy \\ Services \\ Noida, India
}

\author{
Ratna Banerjee \\ School of Business, \\ University of Petroleum \& \\ Energy Studies Dehradun, \\ India
}

\author{
Veena Aggarwal \\ Recventures Education \\ Services Private Limited \\ Delhi, India
}

\author{
Remica Aggarwal \\ MIT-SOER, MIT-ADT \\ University \\ Pune, India
}

\begin{abstract}
Present research tries to study the inter-relationship amongst the various success factors behind the e-tailing of female apparels with the help of ISM methodology.
\end{abstract}

\section{Keywords}

e-tailing; ISM methodology; Female apparels

\section{INTRODUCTION}

The concepts of e-commerce and e-marketplace have revolutionized the fashion industry in more than one way. Not only can one shop from the convenience of the home, one can ensure that favored brands will still find a way into ones wardrobe. Research has proved that apparel sales on $e$ commerce portals have soared beyond the expectation while surpassing the sales of all other categories. B2C growth analysis reports from around the world, especially India, have shown that the influence of the Internet in dictating purchases and shaping sales patterns has increased significantly.

With changing demographics and an increase in the quality of life of urban people, the Indian retail sector is poised for a boom. Currently estimated at $\$ 500$ billion, it is forecast to reach $\$ 1$ trillion in 2020 . However, with $0.1 \%$ penetration, the online market presently constitutes only $\$ 500$ million of the total retail market, but is expected to grow 140 times and reach $\$ 70$ billion by 2020 , thanks to the demand from the socalled Generation Z. In the last two years, the $\$ 130$ million apparel e-retailing space has attracted investments worth $\$ 70$ million i.e. $40 \%$ of the total funding Indian e-retailers bagged during the period. In fact, the recent inflow of private equity investment into many garment start-ups is an indication that the apparel e-tailing platform is reaching a tipping point fast. Many PE and VC firms have invested between $\$ 5$ million and \$52 million in portals like Letsbuy.com, Flipkart.com, FashionAndYou.com, Yebhi.com, and Snapdeal.com [1-5].

This growth story of e-commerce is not devoid of challenges common to the industry, both globally and locally. Consumers, for the longest time, have been accustomed to going to a store and shopping for their apparel and jewellery. Online shopping is a drastic shift for traditional shoppers as they can't "touch and feel" the products. Also, e-commerce in India is in its infancy and the available infrastructure is still inadequate. Lack of common taxation rules further hinder growth in this segment. Inter-state movement of products often poses a problem given the different taxation rates. Other challenges include sub-optimal logistics and infrastructural bottlenecks ,

Inability to convert returns into retails However, brands and retailers have to understand that it is not merely about setting up a portal and creating an $e$-catalogue.
Still there are various factors behind the success of $e$-tailing in India particularly with women wear. Present research work therefore aims to explore various facilitating factors for e-tailing particularly in India. The paper is arranged as follows: section 2 presents the review of various success factors . section 3 explains the ISM methodology . Section 4 , the case example and section 5 the conclusions and managerial implications .

\section{REVIEW OF LITERATURE ON FACILITATING FACTORS FOR E- TAILING IN INDIA 1-3 [1-6]}

1. Regional and traditional garments [ RTG] : Right from special variants of ethnic wedding dresses to traditional costumes, e-tailing has brought India's handicraft heritage into the limelight. Originally ignored or limited geographies have constrained the sales of traditional wear sales. When the traditional silk or cotton sarees are marketed on online portal, their sales increases due to increase level of awareness.

2. Buzz amongst youngsters [BAY] : Apparel, accessories, jewellery, footwear, books, games, electronics are getting popular amongst the age group of 15-35 years. It's important to consider this range because there are many different types of young audiences that can be taken care of by $e$ commerce portals. There are teenagers, collegians, working men and women .

3. Wider target audience [WTA] : The role that $e$ commerce plays in popularising apparel fashion cannot be limited to a state or even a country's borders. One of the biggest contributions of the $e$ commerce revolution to apparel fashion is that it has brought the world a lot closer and bound it together in yarns and weaves, literally and figuratively. Right from Milan and Paris to the glamorous red carpet events in the United States of America, elements of foreign fashion are no longer foreign.

4. Offering helpful tips and tricks [ OHTT] : Apparel fashion tips like what top to wear, with which lower or footwear and for what occasion, happening styles and types, which apparel goes best with which body type, are just some of the many articles one might find on such websites. For the more advanced strategists, $e$-commerce sites are ideal for spreading useful information.

5. Apparel e-tailers ability [AEA] : Currently, huge opportunities lie ahead for the apparel e-tailers. Apart from the infrastructure adequacy, its 
proliferation will depend on apparel $e$-tailers ability to overcome the said challenges. Though consumers in small towns have started using the Internet actively, the transformation from visitors to shoppers will take some time.

6. Upcoming technologies [UT] : Factors such as dramatic increase in penetration of IT devices and communication solutions (especially tablets, broadband and smart-telephony) and emergence of exciting new "virtual reality" technologies are contributing to the expansion of apparel e-tailing. High resolution graphics, streaming videos of garments donned by models, virtual dressing rooms and $360^{\circ}$ viewing and zoom tools have made online shopping an interesting exercise.

7. Time poverty $[\mathbf{T P}]:$ The average Indian consumer has been experiencing increasing time-poverty these days. People have been spending more time commuting to and at their offices, on leisure and recreation, on vacations, in grooming and maintaining their well-being, socializing, teaching school-going children etc. leading to limited time available for shopping and such activities. Convenience in terms of ease and time, information, decision-making, transactions and flexibility has been a major factor influencing adoption of $e$ commerce.

8. Miscellaneous factors [MF] : The consumer mindset, engagement, aftersales service and supply chain, personalization, variety of offerings, return policies and convenience thereof and above all a greater value proposition to the consumer are some of the key success factors.

9. Growth of digital penetration[GDP]: India is in the midst of a digital revolution. The number of Internet users is likely to cross 650 million by 2020 and it is expected that half of the Indian population will be online in the next 3 years. The availability and affordability of smartphones with access to cheap internet data coupled with the rise in disposable income is fueling the growth of digital penetration.

10. Reach of e-retail channel [RC]: In next 3-4 years, more than half of India's incremental Internet growth is expected to come from rural India. Additionally, the digital user demographic is expected to expand beyond the traditional stereotype, with a significant growth in female and older Internet users by 2020 . This will result in a larger market size across different geographies, age and genders and not just a small targeted group.

11. Increasing fashion demands [ IFD] : Limited reach of brick and mortar retail outlets of brands in smaller cities provides an opportunity for online retailers. Heavy discounts and promotions, availability of exclusive products, customized experience, availability of global brands, etc. have made consumers residing in Tier -II and -III cities and semi-urban areas migrate to these online channels.

12. Improved supply chain and end delivery logistics [EDL] : E-commerce business is completely dependent on effective supply chain management.
For customer acquisition from traditional way of brick-and-mortar channel and their retention, it is necessary to provide customized shopping experience to the consumer by giving several convenience options like various payment options, mode of delivery, point of delivery, etc.

13. Growth of private labels [GPL] : With increasing acceptability of private labels among Indian consumers, e-retailers are entering into this emerging segment. This helps online retailers to increase their revenues owing to lower distribution overheads, lesser number of intermediaries and negligible marketing cost involved in private labels.

\section{INTERPRETIVE STRUCTURAL MODELLING METHODOLOGY}

Proposed by Warfield [7], ISM methodology is a technique for establishing inter-relationships amongst the criteria of interest. The process begins with the identification of relevant elements and thereafter establishing contextual relationship amongst them . After that the structural self - interaction matrix (SSIM) is created using the VAXO concept which is then followed by the creation of initial reachability matrix . Final reachability matrix is then created after correcting the initial reachability matrix for any possibility of transitivity . From the reachability matrix, the reachability set and antecedent set for each criterion is found. Then the intersection of these sets is derived for all elements. The element for which the reachability and intersection sets are the same is the top-level element. Then the reachability matrix is converted into the canonical matrix format by arranging the elements according to their levels. Based on the relative driving power and dependence power, factors are classified in various categories like autonomous, dependent, driver and linkage. Finally, a diagraph is constructed from the canonical matrix

\section{DEVELOPMENT OF ISM MODEL : CASE EXAMPLE}

Around 13 challenges have been recognized viz. Sales of Regional and traditional garments [SRTG]; Buzz amongst youngsters [BAY]; Wider target audience [WTA]; Offering helpful tips and tricks [OHTT] ; Apparel e-tailers ability [AEA] ; Upcoming technologies [UT] ; Time poverty [TP] ; Miscellaneous factors $[\mathrm{MF}]$; Growth of digital penetration[GDP]; Reach of e-retail channel [RC]; Increasing fashion demands [ IFD] ; Improved supply chain and end delivery logistics [EDL]; Growth of private labels [GPL] which are now further studied for the possible interrelationship amongst them using ISM methodology.

\subsection{Construction of Structural self- interaction Matrix (SSIM)}

This matrix gives the pair-wise relationship between two variables i.e. $i$ and $j$ based on VAXO. SSIM has been presented below in Fig 1.

\subsection{Construction of Initial Reachability Matrix and final reachability matrix}

The SSIM has been converted in to a binary matrix called the initial reachability matrix shown in fig. 2 by substituting V, A, $\mathrm{X}, \mathrm{O}$ by 1 or 0 as per the case. After incorporating the transitivity, the final reachability matrix is shown below in the Fig 3. 


\begin{tabular}{|c|c|c|c|c|c|c|c|c|c|c|c|c|c|c|}
\hline & Barriers & 1 & 2 & 3 & 4 & 5 & 6 & 7 & 8 & 9 & 10 & 11 & 12 & 13 \\
\hline & & $\begin{array}{c}\text { SRT } \\
\text { G }\end{array}$ & BAY & WTA & $\begin{array}{c}\text { OH } \\
\text { TT }\end{array}$ & $\begin{array}{c}\text { AE } \\
\text { A }\end{array}$ & UT & TP & MF & GDP & RC & $\begin{array}{c}\text { IF } \\
\text { D }\end{array}$ & EDL & GPL \\
\hline 1 & SRTG & & A & A & A & A & A & A & A & A & A & A & A & A \\
\hline 3 & BAY & & & V & A & A & A & A & X & X & V & X & X & A \\
\hline 4 & OHTT & & & & A & A & A & A & A & A & A & X & X & A \\
\hline 5 & AEA & & & & & & A & A & A & A & A & A & A & A \\
\hline 6 & UT & & & & & & & X & X & X & X & X & X & X \\
\hline 7 & TP & & & & & & & & V & V & V & V & V & V \\
\hline 8 & MF & & & & & & & & & X & X & X & X & X \\
\hline 9 & GDP & & & & & & & & & & X & X & X & X \\
\hline 10 & RC & & & & & & & & & & & A & A & A \\
\hline 11 & IFD & & & & & & & & & & & & A & A \\
\hline 12 & EDL & & & & & & & & & & & & & V \\
\hline 13 & GPL & & & & & & & & & & & & & A \\
\hline
\end{tabular}

Fig 1: SSIM matrix for pair wise relationship amongst barriers

\begin{tabular}{|c|c|c|c|c|c|c|c|c|c|c|c|c|c|c|}
\hline & Barriers & 1 & 2 & 3 & 4 & 5 & 6 & 7 & 8 & 9 & 10 & 11 & 12 & 13 \\
\hline & & $\begin{array}{c}\text { SRT } \\
\text { G }\end{array}$ & BAY & WTA & $\begin{array}{c}\text { OH } \\
\text { TT }\end{array}$ & $\begin{array}{c}\text { AE } \\
\text { A }\end{array}$ & UT & TP & MF & GDP & RC & $\begin{array}{c}\text { IF } \\
\text { D }\end{array}$ & EDL & GPL \\
\hline 1 & SRTG & 1 & 0 & 0 & 0 & 0 & 0 & 0 & 0 & 0 & 0 & 0 & 0 & 0 \\
\hline 2 & BAY & 1 & 1 & 1 & 0 & 0 & 0 & 0 & 1 & 1 & 1 & 1 & 1 & 0 \\
\hline 3 & WTA & 1 & 0 & 1 & 0 & 0 & 0 & 0 & 0 & 0 & 0 & 1 & 1 & 0 \\
\hline 4 & OHTT & 1 & 1 & 1 & 1 & 0 & 0 & 0 & 0 & 0 & 1 & 1 & 1 & 1 \\
\hline 5 & AEA & 1 & 1 & 1 & 1 & 1 & 0 & 0 & 0 & 0 & 0 & 0 & 0 & 0 \\
\hline 6 & UT & 1 & 1 & 1 & 1 & 1 & 1 & 1 & 1 & 1 & 1 & 1 & 1 & 1 \\
\hline 7 & TP & 1 & 1 & 1 & 1 & 1 & 1 & 1 & 1 & 1 & 1 & 1 & 1 & 1 \\
\hline 8 & MF & 1 & 1 & 1 & 1 & 1 & 1 & 0 & 1 & 1 & 1 & 1 & 1 & 1 \\
\hline 9 & GDP & 1 & 1 & 1 & 1 & 1 & 1 & 0 & 1 & 1 & 1 & 1 & 1 & 1 \\
\hline 10 & RC & 1 & 0 & 1 & 1 & 1 & 1 & 0 & 1 & 1 & 1 & 0 & 0 & 0 \\
\hline 11 & IFD & 1 & 1 & 1 & 1 & 1 & 1 & 0 & 1 & 1 & 1 & 1 & 0 & 0 \\
\hline 12 & EDL & 1 & 1 & 1 & 1 & 1 & 1 & 0 & 1 & 1 & 1 & 1 & 1 & 1 \\
\hline 13 & GPL & 1 & 1 & 1 & 1 & 1 & 1 & 0 & 1 & 1 & 1 & 1 & 0 & 1 \\
\hline
\end{tabular}

Fig 2: Initial reachability matrix

\begin{tabular}{|c|c|c|c|c|c|c|c|c|c|c|c|c|c|c|c|}
\hline & Barriers & 1 & 2 & 3 & 4 & 5 & 6 & 7 & 8 & 9 & 10 & 11 & 12 & 13 & \\
\hline & & $\begin{array}{c}\text { SRT } \\
\text { G }\end{array}$ & $\begin{array}{c}\text { BA } \\
\text { Y }\end{array}$ & WTA & $\begin{array}{c}\text { OH } \\
\text { TT }\end{array}$ & $\begin{array}{c}\text { AE } \\
\text { A }\end{array}$ & UT & TP & MF & GDP & RC & $\begin{array}{c}\text { IF } \\
\text { D }\end{array}$ & EDL & GPL & D.P \\
\hline 1 & SRTG & 1 & 0 & 0 & 0 & 0 & 0 & 0 & 0 & 0 & 0 & 0 & 0 & 0 & 1 \\
\hline 2 & BAY & 1 & 1 & 1 & 1 & 1 & 1 & 0 & 1 & 1 & 1 & 1 & 1 & 0 & 11 \\
\hline 3 & WTA & 1 & 1 & 1 & 1 & 1 & 1 & 0 & 1 & 1 & 1 & 1 & 1 & 0 & 10 \\
\hline 4 & OHTT & 1 & 1 & 1 & 1 & 1 & 1 & 0 & 1 & 1 & 1 & 1 & 1 & 1 & 12 \\
\hline 5 & AEA & 1 & 1 & 1 & 1 & 1 & 0 & 0 & 0 & 0 & 1 & 1 & 1 & 1 & 9 \\
\hline
\end{tabular}




\begin{tabular}{|c|c|c|c|c|c|c|c|c|c|c|c|c|c|c|c|}
\hline 6 & UT & 1 & 1 & 1 & 1 & 1 & 1 & 1 & 1 & 1 & 1 & 1 & 1 & 1 & 13 \\
\hline 7 & TP & 1 & 1 & 1 & 1 & 1 & 1 & 1 & 1 & 1 & 1 & 1 & 1 & 1 & 13 \\
\hline 8 & MF & 1 & 1 & 1 & 1 & 1 & 1 & 1 & 1 & 1 & 1 & 1 & 1 & 1 & 13 \\
\hline 9 & GDP & 1 & 1 & 1 & 1 & 1 & 1 & 1 & 1 & 1 & 1 & 1 & 1 & 1 & 13 \\
\hline 10 & RC & 1 & 1 & 1 & 1 & 1 & 1 & 1 & 1 & 1 & 1 & 1 & 1 & 1 & 13 \\
\hline 11 & IFD & 1 & 1 & 1 & 1 & 1 & 1 & 1 & 1 & 1 & 1 & 1 & 1 & 0 & 12 \\
\hline 12 & EDL & 1 & 1 & 1 & 1 & 1 & 1 & 1 & 1 & 1 & 1 & 1 & 1 & 1 & 13 \\
\hline 13 & GPL & 1 & 1 & 1 & 1 & 1 & 1 & 1 & 1 & 1 & 1 & 1 & 1 & 1 & 13 \\
\hline & De.P & 13 & 12 & 12 & 12 & 12 & 11 & 8 & 11 & 11 & 12 & 12 & 12 & 9 & \\
\hline
\end{tabular}

Fig 3: Final reachability matrix

\subsection{Level Partition}

Table 4.3.1 Iteration I

\begin{tabular}{|c|c|c|c|c|}
\hline S.No & $\begin{array}{l}\text { Reachabil } \\
\text { ity set }\end{array}$ & $\begin{array}{l}\text { Antecedent } \\
\text { set }\end{array}$ & $\begin{array}{c}\text { Intersectio } \\
\text { n set }\end{array}$ & Level \\
\hline 1 & 1 & $\begin{array}{l}1,2,3,4,5,6,7,8 \\
9,10,11,12,13\end{array}$ & 1 & \multirow{5}{*}{ I } \\
\hline 2 & $\begin{array}{l}1,2,3,4,5, \\
10,11,12\end{array}$ & $\begin{array}{c}2,3,4,5,6,7,8,9 \\
, 10,11,12,13\end{array}$ & $\begin{array}{c}2,3,4,5,10 \\
11,12\end{array}$ & \\
\hline 3 & $\begin{array}{c}1,2,3,4,5,6 \\
8,9,10,11, \\
12\end{array}$ & $\begin{array}{c}2,3,4,6,7,8,9 \\
10,11,12,13\end{array}$ & $\begin{array}{c}2,3,4,6,8,9 \\
10,11,12\end{array}$ & \\
\hline 4 & $\begin{array}{c}1,2,3,4,5,6 \\
8,9,10,11 \\
12,13\end{array}$ & $\begin{array}{c}4,6,7,8,9,10, \\
12,13\end{array}$ & $\begin{array}{c}4,6,8,9,10 \\
12,13\end{array}$ & \\
\hline 5 & $\begin{array}{c}1,2,3,4,5,6 \\
7,8,9,10,11 \\
, 12,13\end{array}$ & $\begin{array}{c}6,7,8,9,10,12 \\
13\end{array}$ & $\begin{array}{c}6,8,9,10,12 \\
, 13\end{array}$ & \\
\hline
\end{tabular}

Table 4.3.2 Iteration II

\begin{tabular}{|c|c|c|c|c|}
\hline S.no & $\begin{array}{c}\text { Reachability } \\
\text { set }\end{array}$ & $\begin{array}{l}\text { Antecedent } \\
\text { set }\end{array}$ & $\begin{array}{c}\text { Intersection } \\
\text { set }\end{array}$ & Level \\
\hline 2 & $\begin{array}{c}2,3,4,5,10 \\
11,12\end{array}$ & $\begin{array}{c}2,3,4,5,6,7,8 \\
9,10,11,12, \\
13\end{array}$ & 5 & \multirow{3}{*}{ II } \\
\hline 3 & $6,8,9,10,11,12$ & $6,7,8,9,13$ & $6,8,9$ & \\
\hline 4 & $6,8,9,13$ & $6,7,8,9,13$ & $6,8,9,13$ & \\
\hline
\end{tabular}

Table 4.3.3 Iteration III

\begin{tabular}{|c|c|c|c|c|}
\hline $\begin{array}{c}\text { S. } \\
\text { no }\end{array}$ & $\begin{array}{c}\text { Reachabilit } \\
\text { y set }\end{array}$ & $\begin{array}{c}\text { Antecedent } \\
\text { set }\end{array}$ & $\begin{array}{c}\text { Level } \\
\text { Intersectio } \\
\text { n set }\end{array}$ & \\
\hline 3 & $6,8,9$ & $6,7,8,9,13$ & $6,8,9$ & \multirow{2}{*}{} \\
\cline { 1 - 4 } 4 & $6,8,9,13$ & $6,7,8,9,13$ & $6,8,9,13$ & \multirow{2}{*}{ III } \\
\hline 5 & $\mathbf{6 , 7 , 8 , 9 , 1 3}$ & $6,7,8,9,13$ & $6,7,8,9,13$ & \\
\hline
\end{tabular}

\section{DRIVING POWER \& DOMINANCE} DIAGRAM

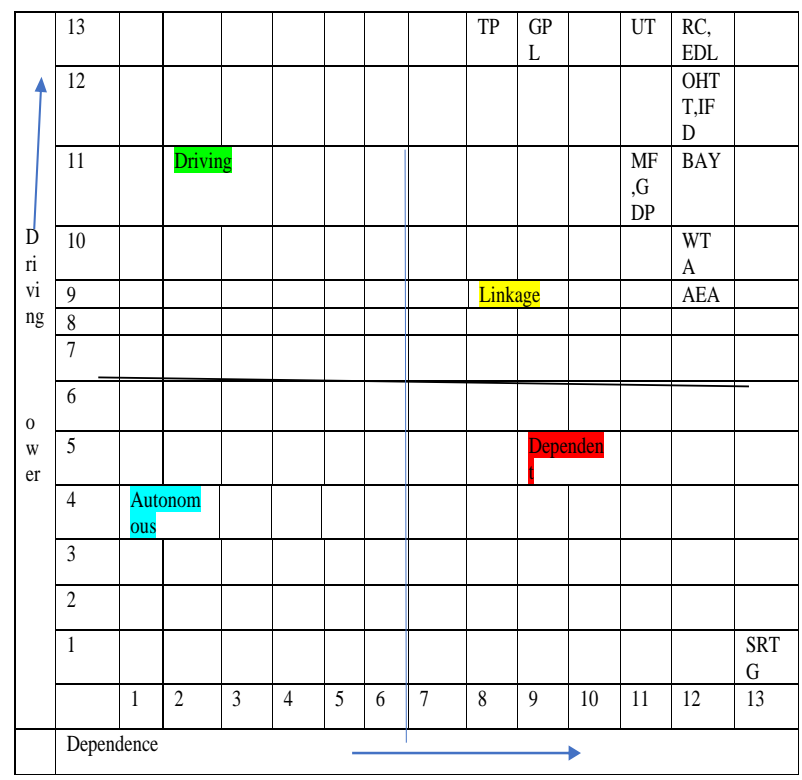

6. ISM DIAGRAPH

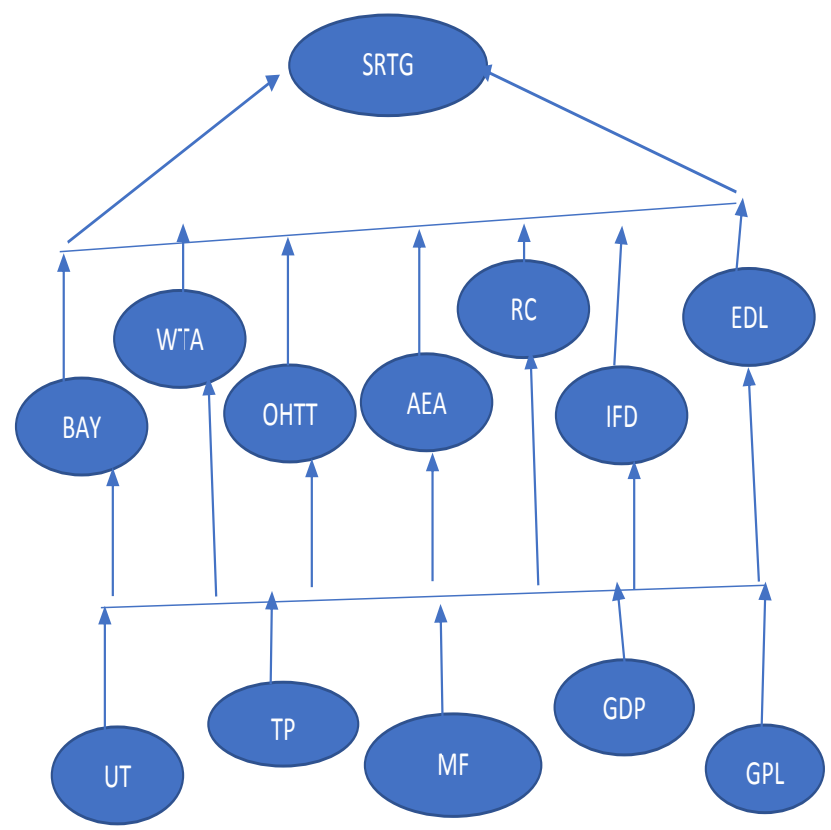

Fig : ISM Diagraph 


\section{ACKNOWLEDGMENTS}

Our thanks to the anonymous reviewers whose comments have helped us in improving the manuscript . Co-author Remica Aggarwal also pay her sincere regards to Prof. S.P Singh of DMS , IIT Delhi for disseminating the knowledge about ISM methodology.

\section{REFERENCES}

[1] Jayakrishnan, S. 2015. e-retailing in India : Opportunities and challenges, International Journal of Research in finance and marketing, 5(3), ISSN 22315985 .

[2] Rajasekar, S. and Sweta Agarwal, S. 2018. A study of impact of e-commerce in India commerce, international journal of developmental research, ISSN 2230-9926. 6(3), 7253-7256.

[3] Frederick, S. Lim, W.T. Jin,X. J Srai, J. S. . 2018. Consumer-driven e-commerce: A literature review, design framework, and research agenda on last-mile logistics models, International Journal of Physical Distribution \& Logistics Management , ISSN: 0960-0035

[4] Laudon, K. C., and Laudon, J. P. 2013.Management Information Systems: Managing the Digital Firm. Twelve Edition. Pearson. Delhi.

[5] Ray, S. 2011.Emerging Trend of E-Commerce inIndia: Some Crucial Issues, Prospects and Challenges, Computer Engineering and Intelligent Systems ISSN 2222-1719. ISSN 2222-2863, 2(5), 2011

[6] Gangeshwer, D. K. 2013. E-Commerce or Internet Marketing: A Business Review from Indian Context, International Journal of $\mathrm{u}$ - and e- Service, Science and Technology, 6(6).

[7] Warfield, J. N. 1974. Developing interconnection matrices in structural modeling. IEEE Transactions on System, Man, and Cybernetics, SMC-4 (1), 81-87. 